\title{
Public policies of electronic governance and corruption in Mexico
}

\author{
Martin Cutberto Vera Martinez \\ Faculty of Economics and International Relations, Autonomous University of Baja California. \\ Address: Calzada Universidad. 14418 Parque Industrial \\ Internacional Tijuana, B.C. México C.P. 22427
}

María Concepción Martínez Rodríguez

Instituto Politécnico Nacional, Centro Interdisciplinario de Investigaciones y Estudios sobre Medio Ambiente y Desarrollo.

Address: Calle 30 de Junio de 1520, Barrio la Laguna Ticomán

C.P. 07340, Del. Gustavo A. Madero, Ciudad de México, México

cross'ref $^{\text {http://dx.doi.org/10.5755/j01.ppaa.19.3.27769 }}$

\begin{abstract}
This article argues that although electronic governance has been institutionalised as a public policy that promotes access to information, transparency and control of public institutions by citizens, the introduction of electronic governance has not immediately generated a positive impact on the reduction of corruption and that, consequently, other complementary actions are necessary in order to execute the public policies of electronic government.
\end{abstract}

Keywords: public policies, electronic governance, corruption, participation, technology. technologijos.

Raktažodžiai: viešoji politika, elektroninè valdžia, korupcija, visuomenès dalyvavimas,

\section{Introduction}

Similarly to other countries worldwide, Mexican public institutions have over time lost legitimacy and credibility with citizens (Homs, 2013) due to multiple factors, but mainly due to issues related to corruption of different government agencies (Stephen, 2011). In this context, throughout the last decades, the process of the public administration reform has developed as a sequence of responses to the inefficiency in political action, lack of credibility of the public sector, bureaucracy, inflexibility, disproportion in terms of costs and displacement of the needs of citizens (Berman, 1997).

Among the different types of responses, technological actions and tools to combat corruption have been developed. In this light, e-government has stood out as a concrete tool used by different administrations to reduce corruption, recover the legitimacy, efficiency and credibility of public organisations (Ruiz, Morales \& Contreras, 2014. Sánchez, 2010). Notably, in the framework of the information age (Serrano Santoyo \& Martínez, 2003, p. 3), electronic government has been considered as a fundamental public policy to reduce corruption.

However, this article will show that even if electronic government is presented as a public policy facilitating transparency and access to information, its implementation does not necessarily translate into a positive impact on the reduction of corruption. Consequently, it will be necessary to reflect on the need to include other complementary elements in the design of e-government public policies to achieve a positive impact on corruption. 
The structure of this article is as follows: first, a theoretical review of electronic government as a public policy and a reference to the phenomenon of corruption are presented. Second, the data collected are discussed. Third, an analysis of the data is given and alternatives in the design of egovernment public policies are proposed. Finally, conclusions and suggestions for future lines of research are presented.

\title{
Theoretical review: electronic government as a public policy that facilitates transparency and reduces corruption
}

As far as electronic government is concerned, there is not yet a definition that can fully cover its complexities, even though specific conceptual approaches can be noted. For example, the IberoAmerican Charter of Electronic Government defines it as the use of information and communication technologies (ICTs) in the Public Administration bodies to improve the information and services offered to citizens, guide the effectiveness and efficiency of public management and substantially increase public sector transparency and citizen participation. Furthermore, the OECD (2003) conceptualises it as the use of information and communication technologies as a tool to achieve better governance. The World Bank defines it as the use that government institutions make of information technologies that can transform relations with citizens, businesses and other branches of the government. In turn, different United Nations reports refer to it as a process by which the government applies ICT to provide information and services to the public. In addition, the Economic Commission for Latin America and the Caribbean (ECLAC) refers to electronic government as a new form of government that bases its application on Public Administration, with the objective of contributing to the use of ICT to improve services and information offered to citizens and organisations, improve and simplify the processes of institutional support and facilitate the creation of channels to increase transparency and citizen participation (ECLAC, 2011, p. 5). Likewise, Gil-García (2007) refers to electronic government as to:

\begin{abstract}
The selection, implementation and use of information and communication technologies in government to provide public services, improve administrative effectiveness and promote democratic values and mechanisms, as well as the development of a regulatory framework that facilitates information-intensive initiatives and promote the knowledge society.
\end{abstract}

\section{(Gant, 2008, p. 15 in Gil-Garcia (2007)}

Thus, the e-government public policy stands out as an open-ended public policy, where transparency has been its central axis (Elster, 1998, p. 101) and where public management (Ontiveros, 2004, p 15) implies favouring accountability to citizens who have the right to demand accurate, reliable and verifiable information on government acts (Doyle, 2003, p. 163). In this context, public policies of electronic government (from here onwards PPGE) promote the idea of transparency of government activities and make general information available to society as an essential factor to combat corruption.

As far as corruption is concerned, it is essential to recognise that it is a complex multifactorial and interdisciplinary phenomenon. In the literature, several terms are used to refer to it. The World Bank defines corruption as the abuse of public power to achieve personal benefits, while for the NGO Transparency International, corruption consists of the abuse of authority granted by political leaders for their benefit or an interest group. These definitions suggest that corruption only occurs among individuals who have a high-level public office; however, citizens can also be partakers of bribery, either as accomplices or as seekers of corrupt acts. In this sense, it is essential to take into account both public officials and citizens for the study of corruption.

Electronic government has been presented as a public policy with a scope of efficiency and effectiveness, a more transparent public administration with a greater accountability and access to public information. Hypothetically, electronic government can result in a more open government and prevent acts of corruption with concrete actions. We observe that PPGE allow four main actions, 
specifically: (a) access to online services; (b) distance training and education; (c) transparency and accountability; (d) citizen participation. Regarding the last two actions, Andersen (2009), SourVargas (2017), Svensson (2005) have indicated that such tools within the framework of electronic government should favour the reduction of corruption.

The purpose of this article is to evaluate whether PPGE have a positive impact on the reduction of corruption. In order to do this, a quantitative analysis of the initiatives related to electronic government and the measurements of corruption in Mexico will be presented.

\section{indicators \\ Data related to e-government public policies and their relationship with corruption}

\section{Relevant data on e-government public policies}

New technologies have brought along the modernisation of government public services to build a more efficient, effective and transparent relationship between the government and citizens (Perez-Zuñiga, Camacho-Castillo, Mena-Hernández and Arroyo Cervantes, 2015). Regarding the actions taken by Mexico in the framework of PPGE, we can identify different legislative and administrative activities related to information and communication technologies until the end of the 1990s. However, a momentous event occurred in 2000, when the National e-Mexico System and the Electronic Government Program were implemented, which consolidated different actions within the framework of PPGE. Subsequently, changes were made to article $6^{\circ}$ of the Mexican Constitution, as well as the promulgation of the Federal Law on Transparency and Access to Government Public Information; the Federal Institute for Transparency and Access to Government Public Information became responsible for guaranteeing access to public information and ensuring compliance with this law. These first initiatives served as the foundation to promote transparency and accountability on government websites.

Table 1 presents the different types of legislative ("Leg."), administrative ("Adm.") and regional ("Reg.") actions that have been carried out in the framework of PPGE in order to promote good governance and contribute to the reduction of the potential number of corrupt acts and increase efficiency and effectiveness in public management through a differentiated way of interacting with citizens.

Table 1. Evolution of e-government public policies in Mexico.

\begin{tabular}{|c|c|c|c|}
\hline YEAR & $\begin{array}{c}\text { TYPE OF } \\
\text { INITIATIVE }\end{array}$ & NAME & OBJECTIVE \\
\hline 1996 & Adm. & CompraNet & $\begin{array}{l}\text { Simplify the procedure for contracting goods, leases, services } \\
\text { and public works of the dependencies and entities of the } \\
\text { Federal Public Administration. }\end{array}$ \\
\hline 2002 & Adm. & The Citizen Portal & $\begin{array}{l}\text { Facilitate access to services provided by the Mexican } \\
\text { government. All information regarding the services and } \\
\text { procedures of the entities that make up the Public } \\
\text { Administration is published. }\end{array}$ \\
\hline 2003 & Reg. & $\begin{array}{l}\text { Electronic Government } \\
\text { Network of Latin America } \\
\text { and the Caribbean }\end{array}$ & $\begin{array}{l}\text { Promote horizontal cooperation between Latin America and } \\
\text { the Caribbean in the use of new ICT information } \\
\text { technologies. }\end{array}$ \\
\hline 2003 & Adm. & $\begin{array}{l}\text { Information request } \\
\text { system (SISI) }\end{array}$ & $\begin{array}{l}\text { Facilitate online access to information and the filing of } \\
\text { corresponding means of defence due to the denial of access } \\
\text { determined by the dependencies and entities of the Federal } \\
\text { Public Administration. }\end{array}$ \\
\hline 2003 & Leg. & $\begin{array}{l}\text { Federal Law on } \\
\text { Transparency and Access } \\
\text { to Government Public } \\
\text { Information (LFTAIPG) }\end{array}$ & $\begin{array}{l}\text { Provide what is necessary at the federal level, guarantee the } \\
\text { right of access to Public Information in possession of any } \\
\text { authority, entity, body and agency of the Legislative, } \\
\text { Executive and Judicial branches, autonomous bodies, } \\
\text { political parties, trusts and public funds as well as of any } \\
\text { natural person that receives and exercises federal public } \\
\text { resources or acts of authority. }\end{array}$ \\
\hline
\end{tabular}




\begin{tabular}{|c|c|c|c|}
\hline YEAR & $\begin{array}{c}\text { TYPE OF } \\
\text { INITIATIVE }\end{array}$ & NAME & OBJECTIVE \\
\hline 2005 & Reg. & $\begin{array}{c}\text { Inter-American } \\
\text { Government Procurement } \\
\text { Network (RIGC) } \\
\end{array}$ & $\begin{array}{l}\text { Create a space for exchanging experiences to strengthen } \\
\text { government procurement practices in the region. }\end{array}$ \\
\hline 2006 & Reg. & $\begin{array}{l}\text { Regional Information } \\
\text { System on Good Public } \\
\text { Management Practices in } \\
\text { Latin America and the } \\
\text { Caribbean (SIPAL) }\end{array}$ & $\begin{array}{l}\text { Gather information on good management practices that } \\
\text { include institutional transparency and disseminate them to } \\
\text { strengthen central public administrations. }\end{array}$ \\
\hline 2006 & Adm. & $\begin{array}{l}\text { Digital Government } \\
\text { Strategy (OPIG) }\end{array}$ & $\begin{array}{l}\text { Optimise information and communication technologies in } \\
\text { order to make government management more efficient, to } \\
\text { provide services of greater quality, to make public functions } \\
\text { in all areas of government transparent and to combat } \\
\text { corruption. }\end{array}$ \\
\hline 2007 & Adm. & $\begin{array}{l}\text { E-SAT Portal of the Tax } \\
\text { Administration Service }\end{array}$ & $\begin{array}{l}\text { Facilitate compliance with the payment of taxes and represent } \\
\text { a mechanism to make the procedure for payment of tax } \\
\text { obligations transparent. }\end{array}$ \\
\hline 2007 & Reg. & $\begin{array}{l}\text { Ibero-American Charter of } \\
\text { Electronic Government }\end{array}$ & $\begin{array}{l}\text { Action promoted by the Latin American Center for } \\
\text { Development Administration (CLAD). Its purpose is to } \\
\text { increase public services and products, to improve efficiency } \\
\text { and transparency in public administration. }\end{array}$ \\
\hline 2007 & Adm. & $\begin{array}{l}\text { Transparency Obligations } \\
\text { Portal (POT) }\end{array}$ & $\begin{array}{l}\text { The portal concentrates the mandatory public information of } \\
\text { the entire Federal Public Administration (APF) as indicated } \\
\text { in Article } 7 \text { of the LFTAIPG. }\end{array}$ \\
\hline 2008 & Adm. & $\begin{array}{l}\text { INFOMEX Federal } \\
\text { Government System } \\
\end{array}$ & $\begin{array}{l}\text { Request information from any entity of the Federal Public } \\
\text { Administration and submit it through the same means. }\end{array}$ \\
\hline 2011 & Adm. & National e-Mexico System & $\begin{array}{l}\text { Allow access to services provided by federal, state and } \\
\text { municipal public administrations. Promote citizen } \\
\text { participation in an agile, efficient, transparent and secure way. } \\
\text { Open } 24 \text { hours a day, } 365 \text { days a year. }\end{array}$ \\
\hline 2015 & Leg. & $\begin{array}{c}\text { General Law on } \\
\text { Transparency and Access } \\
\text { to Public Information } \\
\text { (LGTAIP) }\end{array}$ & $\begin{array}{l}\text { Establish the principles, general bases and procedures to } \\
\text { guarantee the right of access to information in the possession } \\
\text { of any authority, entity, organ and body of the Legislative, } \\
\text { Executive and Judicial branches, autonomous bodies, } \\
\text { political parties, trusts and public funds as well as of any } \\
\text { person that receives and exercises public resources or acts of } \\
\text { authority of the Federation, the Federative Entities and the } \\
\text { municipalities. }\end{array}$ \\
\hline 2016 & Adm. & $\begin{array}{l}\text { National Transparency } \\
\text { Platform (PNT) }\end{array}$ & $\begin{array}{l}\text { An electronic platform that allows compliance with the } \\
\text { procedures, obligations and provisions established in the laws } \\
\text { on transparency, attending to the users' needs of accessibility. }\end{array}$ \\
\hline 2017 & Adm. & $\begin{array}{l}\text { System of Transparency } \\
\text { Obligations Portals } \\
\text { (SIPOT) }\end{array}$ & $\begin{array}{l}\text { Module of the National Transparency Platform through which } \\
\text { citizens can consult the public information of the obligated } \\
\text { subjects of each of the federative entities and the Federation. }\end{array}$ \\
\hline
\end{tabular}

Source: Authors.

On the other hand, within the available data on electronic government, we have found different international and national sources. For example, at the federal level, we see the State Digital Governance Index (IGDE), carried out by the Civil Association "Computing Committee of the State and Municipal Public Administration" (CIAPEM). Such an index was created to measure how Internet portals and social networks of Mexican government entities contribute to transparency, accountability, participation and citizen empowerment. In 2018, CIAPEM published a global value to evaluate the Mexican government: 30.69 points out of 100. In addition, the State Electronic Government Index (IGEE) has measured progress in each of the states since 2004, but this index does not give a global value to all of Mexico.

At the international level, the primary source of consultation is the United Nations Survey (EGovernment Survey) that reports the trends of electronic government as well as promotes the 
application of technological solutions to improve education, health, the environment and employability. The Electronic Government Development Index (EGDI) is the name of the value that measures the evolution and implementation of the electronic government in each country explicitly.

Table 2 presents the values of the Mexican government and its position in the global ranking. It should be noted that from 2003 to 2005, the measurement was annual, but from 2008 to 2018, the frequency was biannual.

Table 2. Position and annual value of the Mexican government in the e-Government Development Index.

\begin{tabular}{|c|c|c|}
\hline YEAR & $\begin{array}{l}\text { RANKING } \\
\text { POSITION }\end{array}$ & $\begin{array}{c}\text { VALUE OF THE ELECTRONIC GOVERNMENT DEVELOPMENT } \\
\text { INDEX (EGDI) }\end{array}$ \\
\hline 2003 & 30 & 0.5933 \\
\hline 2004 & 30 & 0.5957 \\
\hline 2005 & 31 & 0.6061 \\
\hline 2008 & 37 & 0.5893 \\
\hline 2010 & 56 & 0.5150 \\
\hline 2012 & 55 & 0.6240 \\
\hline 2014 & 63 & 0.5733 \\
\hline 2016 & 59 & 0.6195 \\
\hline 2018 & 64 & 0.6818 \\
\hline
\end{tabular}

Source: Authors.

The last index at the international level is independent of the EGDI. It is about the measurement of citizen participation in online public affairs, i.e. "e-participation." This concept includes (a) the provision of information; (b) the involvement of interested parties in contributions and deliberations on public policies and services; (c) participation in decision-making processes and co-creation of service components and delivery modalities.

Table 3. Position in the world ranking and value of the e-Participation Index.

\begin{tabular}{|c|c|c|}
\hline YEAR & RANKING POSITION & INDEX VALUE OF E-PARTICIPATION \\
\hline 2003 & 11 & 0.6034 \\
\hline 2004 & 6 & 0.7705 \\
\hline 2005 & 7 & 0.7619 \\
\hline 2008 & 7 & 0.7500 \\
\hline 2010 & 32 & 0.3714 \\
\hline 2012 & 25 & 0.5789 \\
\hline 2014 & 45 & 0.6078 \\
\hline 2016 & 14 & 0.8814 \\
\hline 2018 & 17 & 0.9438 \\
\hline
\end{tabular}

Source: Authors.

Regarding the e-Participation Index (EPI), Mexico obtained relatively stable scores between 2003 and 2008, suffered a significant fall in 2010 and then increased its score. Although the score increased significantly between 2016 and 2018, this increase was not reflected in the global ranking, where there was a fall from the 14th place to the 17th place due to a substantial global growth in the scores of other countries.

\section{Data on corruption in Mexico}

The analysis of data on corruption shows that some methodologies have been developed to estimate their real dimensions. The best known methodology of the Corruption Perception Index has been developed by the non-governmental organisation Transparency International. This organisation annually awards a score for each country and has built a world ranking since 1998. 
At the national level, the local chapter of the same NGO has created the National Corruption and Good Governance Index (INCBC). This index records hypothetical cases of payment of bribes in 35 public services provided by three levels of government and private companies. It uses a scale from 0 to 100, where a lower degree of corruption is designated at a lower value. Since 2001, the research has been carried out every two years, but since 2010 no new studies have been published.

This analytical instrument does not only measure the citizens' perception of corruption, the number and cost of acts of bribery incurred by citizens, and record the frequency with which acts of crime occur when obtaining public services, but also allows the evaluation of progress in the fight against corruption and facilitates the identification of responsibilities at different levels of government and in the private sector. It measures Mexican citizens' experiences with and perceptions of corruption in 32 federal entities of the country and 38 public services.

According to both sources, in recent years, the situation in Mexico has been unsatisfactory in terms of abuse of power, hidden agreements and bribes. Recurrently, reports reiterate that Mexico is among the most corrupt countries and can be characterised by the loss of general confidence. Such levels of negative perception indicate a high proliferation of corrupt practices (Arellano Trejo, 2012). According to Morris (1991), widespread corruption and its proliferation in civil life is due to the social normalisation of corruption in certain sectors of the population, emergence of a distorted morality in the middle class, deviation of individual responsibility and diffusion of distrust and cynicism towards the government and public officials. In addition, among Latin American countries, the situation of Mexico as a country is no longer favourable.

Several international and national surveys agree that Mexican citizens register the highest levels of perception of corruption and tolerance towards corrupt practices. Two studies have also shown that when in Mexico voters were given information on corruption levels, the population responded with political apathy and voted in smaller numbers. This indicates that citizens simply do not trust that their claims about the actions of the public sector are sufficient to change the behaviour within the public sector and solve historical problems (Fuenmayor, 2004).

The next section will be dedicated to the analysis of the data obtained. Furthermore, the relationship between electronic government and corruption will be discussed.

\section{Analysis of the results}

The emergence of a networked society has marked the end of one era and the beginning of another, i.e. the information age (Castells, 1995, p. 51), where the impact of digitalisation on society is evident and increasingly broader (Santoyo Serrano \& Martínez, 2003, p. 3). In this context, the role of electronic government with regard to corruption begins the debate on the value of the public policy (Cázares and Cejudo, 2013, p. 36)

According to the data presented in the previous section, throughout the last years, the different government actions within the framework of PPGE have been very well received by the national and international community not only from a legislative or administrative point of view, but also with respect to other countries in the world that are well below the average in comparison to Mexico. However, the comparison of the results with those concerning national corruption shows definite differences in their interrelation.

The classical theory of transparency tends to argue that the openness of the government, supported by specific actions within the framework of electronic government, has a positive impact on corruption rates since, given greater transparency and citizen access, there would be fewer opportunities to enable a space for corrupt acts. However, the contrast shown in the data presented in the previous section requires a more exhaustive analysis of the relationship between public policies of electronic government and corruption.

Importantly, PPGE as such do not entail the solution for the reduction of corruption. Thus, after analysing the evolution of PPGE and the small decrease in corruption rates, we can conclude that the former has not yet been able to harmonise their objectives with greater citizen participation. 
This demonstrates a lack of direct impact on the different actions of electronic government and the reduction of corruption in Mexico.

In the light of the data and arguments presented in this article, we argue that a political and organisational construction that pays attention to very different factors (Gil-García, 2012) is needed in order to avoid that PPGE become merely technological actions that trigger specific results. It is important to consider what is necessary for public policies of e-government to promote definite conclusions regarding the decrease in corruption in Mexico.

\section{Conclusions}

1. A more comprehensive view of the phenomenon is required as well as new bases of action linked to networks in their broadest sense.

2. For the latter to crystallise, it would be necessary not only for the government to be able to respond to the needs of its citizens in terms of legitimacy, but also to identify and define users' needs in consultation with them. An evaluation of the design of the policies and structures that promote transparency as well as the suitability of the organisation that implements them and the results of public action should be considered.

3. Analysing the management of policies aimed at reducing corruption solely from a governmental approach, considering that a corrupt act is due to a crime of calculation and opportunity without any relation to other factors, would imply incurring a reductionism and would not answer our initial question, i.e. the need to identify other tools within e-government policies in order to positively influence a specific result that reduces corruption rates.

4. Based on the above, the approach to these problems requires addressing the underlying economic, political and institutional and, above all, cultural causes.

5. The results of the present work show perceptible results regarding the lack of symmetry between PPGE and corruption indexes. The latter show very little progress in the fight against corruption, despite the increasing number of conventions, international conventions, approval of new legislation in various countries, etc.

6. The lack of participation is the citizens' response to the loss of credibility of the public sector. Bureaucracy, inflexibility, inefficiency, the disproportion in terms of costs and distance from the needs of citizens are part of the problem.

7.If we extend these reflections to PPGE, we can affirm that the complementary element translates into the participation of citizens in the control of online information, or e-participation, where such participation is evidenced by a greater control of the government's actions regarding electronic government and a greater transparency online. We see how the classic administrative concepts are translated into new ideas influenced by technology, where e-government has a direct link with e-participation and the reduction of corruption.

8. Mexico's most important challenge in e-participation is to make citizens demand more from the government in their different actions related to PPGE, to strengthen the citizen-governed trust in authorities accountable to it.

9. In conclusion, an increase in citizen participation online can translate into a positive impact on reducing corruption rates and re-establishing a symmetry between PPGE and corruption rates in Mexico.

\section{References}

1. Andersen, T. B. (2009). E-Government as an anti-corruption strategy. Information Economics and Policy, 21(3), 201-210. doi: 10.1016/j.infoecopol.2008.11.003

2. Arellano Trejo, E. (2012). Impacto de la corrupción en la desconfianza política. La cultura de la corrupción en México. Recuperado de http://www3.diputados.gob.mx/camara/content/do wnload/21275/105802/file/PB4004\%20Impacto\%20de\%20la\%20corrupcion\%20en\%20la\% 20desconfianza\%20pol\%C3\%ADtica.pdf 
3. Bertot, J. C., Jaeger, P. T., \& Grimes, J. M. (2010). Using ICTs to create a culture of transparency E-government and social media as openness and anti-corruption tools for societies. Government Information Quarterly, 27(3), 264-271. doi: 10.1016/j.giq.2010.03.001

4. Berman, S. (1997). Children's social consciousness and the development of social responsibility. New York: New York State University Press.

5. Castells, M. (1995). La ciudad informacional. Tecnologías de la Información, reestructuración económica y el proceso urbano-regional, Madrid: Alianza Editorial.

6. Cázares, A. y Cejudo, G. (2013). "El acceso a la información gubernamental: análisis empírico de políticas de transparencia en cuatro países centroamericanos". Revista de Gestión $\begin{array}{lllll}\text { Pública } & 2 & (2), & 35-38 . & \text { ecuperado }\end{array}$ http://www.revistadegestionpublica.cl/Vol_II_No_2/RiosCejudo.pdf

7. Centro Latinoamericano de Administración para el Desarrollo: CLAD (2011). Carta Iberoamericana de Gobierno Electrónico. XVII Cumbre Iberoamericana, Chile, noviembre de 2011. www.bnp.gob.pe/portalbnp/pdf/transparencia/normaslegales/2010/jun/carta_iberoamericana _de_gobierno_electronico.pdf

8. Chowdhury, N. M. (2007). An Empirical Analysis of Selected Factors Affecting Corruption in the Asia-Pacific Region. Ritsumeikan Journal of Asia Pacific Studies, 27, 1-14.

9. Doyle, K. (2003). Comentarios sobre la Ley Federal de Transparencia y Acceso a la Información Pública Gubernamental. Derecho Comparado de la Información, (2), 163-172.

10. Elster, J. (1998). Deliberation and Constitution Making. En Deliberative Democracy. (pp. 97118). Cambridge: Cambridge University Press.

11. Fuenmayor, A. (2004). El derecho de acceso de los Ciudadanos a la Información Pública. Oficina de la UNESCO para Centroamérica, pp. 11-25. Recuperado de http://portal.unesco.org/es/file_download.php/561ff4bc2719856c5184270296fc48f5EL+DE RECHO+DE+ACCESO+DE+LOS+CIUDADANOS+A+LA+INFORMACION+PUBLICA .pdf

12. Gant, Jon P. (2008). Electronic Government for Developing Countries. Geneva, ITU.

13. Gil-García, J. R. (2012), "Even if We Build it, They Will not Come: Reformas de e-gobierno en México (2000-2009)", en M.A. Valverde Loya y M. Hilderbrand (coords.), ¿Transformación, lo mismo de siempre, o progreso lento y con tropiezos? Reformas recientes al sector público en México, México, Escuela de Graduados en Administración Pública, Instituto Tecnológico de Estudios Superiores de Monterrey/Harvard Kennedy School/Miguel Ángel Porrúa.

14. Homs, R., (2013), Marketing para el liderazgo político y social: autoridad y poder, como obtenerlos y retenerlos, México: Random House Mondadori S.A. de C.V., disponible en https://esfops.files.wordpress.com/2013/09/marketing_para_el_liderazgo_politico_y_social. pdf (fecha de consulta: 12 de julio de 2018).

15. Morris, S. (1991). Corrupción y Política en el México Contemporáneo. México: Ed. Siglo veintiuno editores.

16. OCDE (2003). La Administración Electrónica: un imperativo. Recuperado de http://www.cca.org.mx/funcionarios/emprendegestionpublica/descargas/4203074E5.pdf

17. Ontiveros, R. (2004) La transparencia en México: Razón, Origen y Consecuencias. Revista de la Facultad de Derecho de México, (244), 13-30.

18. Perez-Zuñiga, R., Camacho-Castillo, O., Mena-Hernández, E. y Arroyo Cervantes, G., (2015), "Análisis general del gobierno electrónico en México", en Revista Paakat, Guadalajara: UAG, disponible

http://www.udgvirtual.udg.mx/paakat/index.php/paakat/article/view/253/376 (fecha de consulta: 12 de julio de 2018).

19. Ruiz Alanís, Leonardo, Morales Gómez, Juan Miguel y Contreras Orozco, Leticia (2014), Perspectivas del Gobierno Electrónico Local en México, México: Instituto de Administración 
Pública del Estado de México, A.C, disponible en http://hdl.handle.net/20.500.11799/49930 (fecha de consulta: 12 de julio de 2018).

20. Serrano Santoyo, A. y Martínez, E. (2003). La brecha digital: Mitos y Realidades, Baja California, pp.1-3

21. Sour-Vargas, L., (2017), “Gobierno electrónico y corrupción en México (2005-2010)”, en eRevista Innovar, México: Universidad Anáhuac México.

22. Svensson, J. "Eight Questions about Corruption", Journal of Economic Perspectives 19, 3, 2005, pp. 19-42.

\section{Martin Cutberto Vera Martinez, María Concepción Martínez Rodríguez \\ Viešoji elektroninès valdžios politika ir korupcija Meksikoje}

Anotacija

Šiame straipsnyje teigiama, kad nors elektroninė valdžia buvo institucionalizuotaa kaip viešoji politika, skatinanti piliečių prieigą prie informacijos, skaidrumą ir viešujų institucijų kontrolę, tai dar nereiškia, kad tokia pažanga padare teigiamą poveikị mažinant korupciją. Elektroninès valdžios viešajai politikai vykdyti reikalingi kiti papildomi veiksmai.

Martin Cutberto Vera Martinez - a full-time professor, Faculty of Economics and International Relations, Autonomous University of Baja California.

E-mail: $\underline{\text { martin.vera@uabc.edu.mx }}$

María Concepción Martínez Rodríguez - PhD in Public Policies, a full-time professor, Instituto Politécnico Nacional, Centro Interdisciplinario de Investigaciones y Estudios sobre Medio Ambiente y Desarrollo.

E-mail: momartinezr@ipn.mx

Martin Cutberto Vera Martinez - profesorius, Ekonomikos ir tarptautinių santykių fakultetas, Žemutinès Kalifornijos autonominis universitetas.

El. paštas: martin.vera@uabc.edu.mx

María Concepción Martínez Rodríguez - viešosios politikos mokslų daktarè, profesorè, Nacionalinis politechnikos institutas, Tarpdisciplininis aplinkos ir plètros tyrimų ir studijų centras.

El. paštas: mcmartinezr@ipn.mx 